\section{INSTTIUT ZA A JAVNE FLANCIE}

\section{Aktualni osvrti}

Institut za javne financije $\cdot$ Smičiklasova $21 \cdot 10000$ Zagreb

Tel. (+385 1) 4886-444, Fax. (+385 1) 4819-365

www.ijf.hr•ured@ijf.hr

\title{
Porezi u Hrvatskoj i u zemljama OECD-a
}

\author{
dr. sc. Mihaela Bronić
}

OECD je 26. studenog 2009. objavio publikaciju Revenue Statistics 1965-2008. ${ }^{1}$ Osnovna je svrha publikacije koja se izdaje svake godine prikazati međunarodno usporedive podatke o poreznim strukturama i poreznom teretu u zemljama OECD-a. Usporedili smo navedene podatke s podacima za Hrvatsku. Ukupan je porezni teret, koji se računa kao udio svih poreza i socijalnih doprinosa u BDP-u, 2007. u Hrvatskoj bio malo manji od prosječnog u zemljama OECD-a. ${ }^{2}$ Osim toga, u Hrvatskoj se 2007, u usporedbi sa zemljama OECD-a, ubiralo manje prihoda od poreza na dobit i dohodak, te imovinskih i ostalih poreza. Istovremeno Hrvatska je ubirala više prihoda od PDV-a, doprinosa za socijalno osiguranje i ostalih poreza na potrošnju (npr. trošarina i carina).

UKUPAN POREZNI TERET Na slici 1. vidljivo je kako se u razdoblju 1965-2007. prosječan porezni teret ${ }^{3}$ u zemljama OECD-a povećao s 25,5 na $35,8 \%$ BDP-a (za $40 \%$ ). Promatrajući samo devetnaest zemalja EU, članica OECD-a, prosječan porezni teret je od 1965. do 2007. godine porastao s 27,6 na 38,8\% BDP-a (za 41\%). Ukupan je porezni teret u Hrvatskoj bio nešto malo manji od prosjeka OECD-a i smanjio se s 36,8 u 2000. na $35,2 \%$ u 2007. (za oko $4 \%$ ).

Važno je napomenuti kako se u Hrvatskoj porezni prihodi priznaju u trenutku naplate (gotovinsko načelo), a u navedenim podacima OECD-a priznaju se kada su nastali bez obzira jesu li stvarno naplaćeni (obračunsko načelo). Stoga bi za potpuniju usporedbu Hrvatske i zemalja OECD-a trebalo i za Hrvatsku uključiti nenaplaćene poreze i doprinose. Ukupni bi porezni teret tada zasigurno bio nešto veći. Teško je reći za koliko jer su za

\footnotetext{
${ }^{1}$ Analiza se temelji na publikaciji OECD, 2009. Revenue statistics 1965 - 2008. Paris: OECD, objavljenoj 26. studenog 2009. Dodatno su korišteni podaci s internet stranica: Ministarstva financija RH (http://www.mfin.hr) i OECD-a (http://www.oecd.org/home/0,2987,en_2649_201185_1_1_1_1_1,00.html).

${ }^{2}$ Organizacija za ekonomsku suradnju i razvoj (engl. Organization for Economic Cooperation and Development OECD) je međunarodna ekonomska organizacija osnovana 1961. godine. OECD se trenutno sastoji od 30 zemalja članica (Austrije, Belgije, Kanade, Danske, Francuske, Njemačke, Grčke, Islanda, Irske, Italije, Luksemburga, Nizozemske, Norveške, Portugala, Španjolske, Švedske, Švicarske, Turske, Ujedinjenog Kraljevstva, Sjedinjenih Američkih Država, Japana, Finske, Australije, Novog Zelanda, Meksika, Češke, Južne Koreje, Mađarske, Poljske i Slovačke).

${ }^{3}$ Neponderirani prosjek udjela ukupnih poreza i doprinosa opće države u BDP-u.
} 
navedeno izračunavanje potrebni precizni podaci o nenaplaćenim porezima i doprinosima za svaku godinu. Međutim, moguće je da bi ukupni porezni teret bio i za nekoliko postotnih poena BDP-a veći. Primjerice prema dostupnim podacima iz rujna 2009. ukupni neplaćeni porezi i doprinosi državi iznosili su 9,5 mlrd. kuna. ${ }^{4}$

\section{Slika 1. Ukupni porezni prihodi kao \% BDP-a (tekuće cijene)}

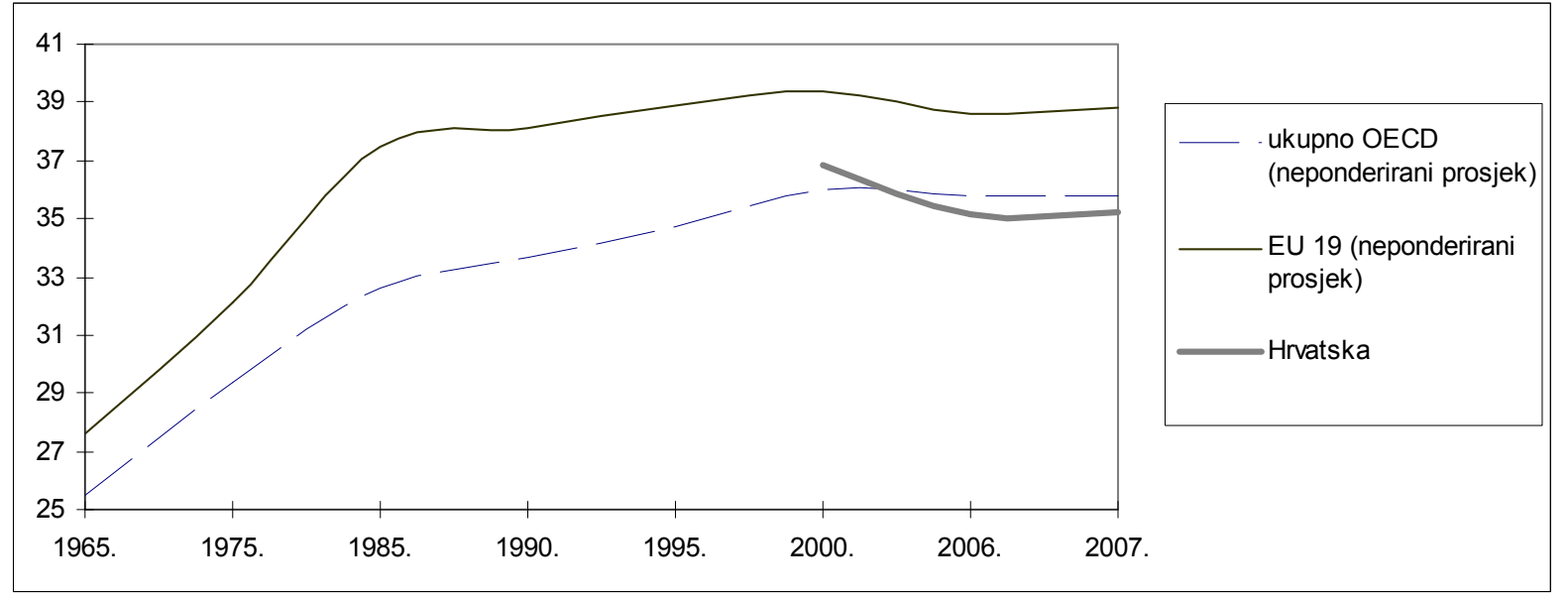

Za Hrvatsku se koriste podaci od 2000. godine, te revidirani BDP u skladu s ESA 95 metodologijom.

EU 19 čine: Austrija, Belgija, Danska, Finska, Francuska, Njemačka, Grčka, Irska, Italija, Luksemburg, Nizozemska, Portugal, Španjolska, Švedska, Ujedinjeno Kraljevstvo, Češka, Mađarska, Poljska i Slovačka.

Izvor: OECD, 2009. Revenue statistics 1965 - 2008. Paris: OECD i podaci Ministarstva financija.

Tabela 1. Ukupni porezni prihodi kao \% BDP-a

\begin{tabular}{|c|c|c|c|}
\hline Odabrana godina & OECD & EU 19 & Hrvatska \\
\hline 1965. & 25,5 & 27,6 & n.p. \\
\hline 1975. & 29,4 & 32,1 & n.p. \\
\hline 1985. & 32,6 & 37,5 & n.p. \\
\hline 1990. & 33,7 & 38,1 & n.p. \\
\hline 1995. & 34,7 & 38,9 & n.p. \\
\hline 2000. & 36,0 & 39,4 & 36,8 \\
\hline 2006. & 35,8 & 38,6 & 35,1 \\
\hline 2007. & 35,8 & 38,8 & 35,2 \\
\hline
\end{tabular}

n.p. = nema podatka

Izvor: Isti kao na Slici 1.

STRUKTURA UKUPNIH POREZNIH PRIHODA Postojale su značajne razlike 2007. u poreznoj strukturi između Hrvatske i prosjeka u zemljama OECD-a (slika 2). U Hrvatskoj se ubiralo manje prihoda od poreza na dohodak (za 64\%) i dobit (za 27\%), te imovinskih poreza (za 83\%) i ostalih poreza. Međutim Hrvatska je ubirala više prihoda od PDV-a (za $79 \%$ ), doprinosa za socijalno osiguranje (za 36\%) te specifičnih poreza na potrošnju (npr. trošarina i carina). Nešto su manje razlike u poreznoj strukturi između Hrvatske i promatranih devetnaest zemalja EU.

\footnotetext{
${ }^{4}$ Hrvatska gospodarska komora, 2009. Likvidnost i solventnost. Dostupno na:

(http://www.hgk.hr/wps/portal/!ut/p/.cmd/cl/.l/hr?legacyWcmClippingUrl=http\%3A\%2F\%2Fhgk.biznet.hr\%2Fhg k\%2Ftekst3.php\%3Fa\%3Db\%26page\%3Dtekst\%26id\%3D377\%26kid\%3D352\%26skid\%3D541).
} 
Slika 2. Porezna struktura (\% ukupnih poreznih prihoda), 2007. godina

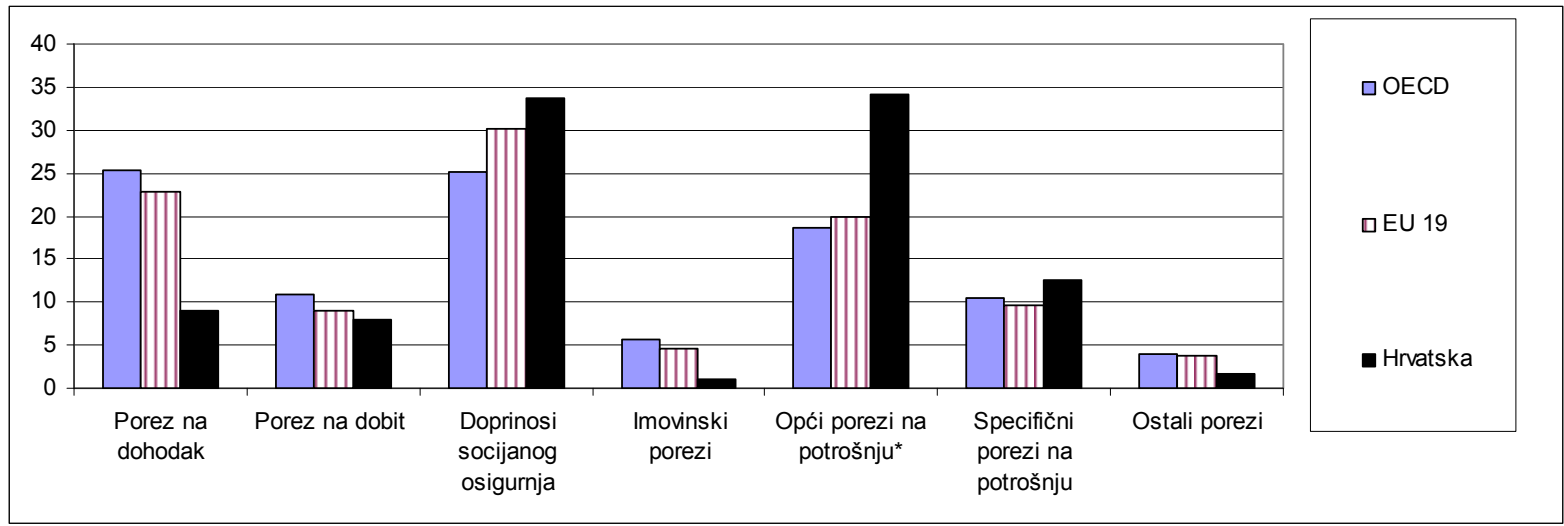

* U većini zemlja uveden je PDV kao opći porez na potrošnju.

Izvor: Isti kao na Slici 1.

Tabela 2. Porezna struktura (\% ukupnih poreznih prihoda), 2007. godina

\begin{tabular}{|l|c|c|c|}
\hline & OECD & EU 19 & Hrvatska \\
\hline Porez na dohodak & 25 & 23 & 9 \\
\hline Porez na dobit & 11 & 9 & 8 \\
\hline Doprinosi socijalnog osiguranja & 25 & 30 & 34 \\
\hline Imovinski porezi & 6 & 5 & 1 \\
\hline Opći porezi na potrošnju & 19 & 20 & 34 \\
\hline Specifični porezi na potrošnju & 11 & 10 & 12 \\
\hline Ostali porezi & 4 & 4 & 2 \\
\hline Ukupno porezni prihodi & $\mathbf{1 0 0}$ & $\mathbf{1 0 0}$ & $\mathbf{1 0 0}$ \\
\hline
\end{tabular}

Za Hrvatsku se koriste podaci od 2000. godine, te revidirani BDP u skladu s ESA 95 metodologijom. Izvor: Isti kao na Slici 1.

ZAKLJUČAK Ukupan je porezni teret 2007. u Hrvatskoj bio malo manji od prosječnog u zemljama OECD-a. Postojale su značajne razlike u poreznoj strukturi između Hrvatske i analiziranih zemalja. U Hrvatskoj je naglasak na oporezivanju potrošnje (PDV i specifični porezi - poput trošarina). Očito je i da bi trebalo smanjiti socijalne doprinose jer su previsoki, a za to je neophodna reforma mirovinskog i socijalnog osiguranja.

Treba napomenuti i da trenutno ne postoje javno dostupni precizni podaci o nenaplaćenim porezima i doprinosima Hrvatskoj čije bi uključivanje u našu analizu omogućilo potpunu usporedivost $\mathrm{s}$ podacima OECD-a, ali nažalost i povećalo pokazatelj udjela poreza u hrvatskom BDP-u. 